НАУКОВИЙ ВІСНИК

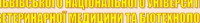

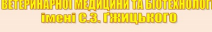

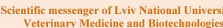
minis

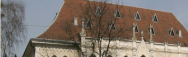
11) IIIMII

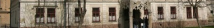
СЕРР: ХАРЧОВі ТЕХнолог ERRIS: FOOD TECHNOL Tом 23 №

\section{Науковий вісник Яьвівського національного університету} ветеринарної медицини та біотехнодогій імені С.3. Гжицького.

Серія: Харчові технологіі

\author{
Scientific Messenger of Lviv National University \\ of Veterinary Medicine and Biotechnologies.
}

Series: Food Technologies doi: 10.32718/nvlvet-f9506

https://nvlvet.com.ua/index.php/food

UDC 621.867 .157

\title{
Increase the functionality of vibration feeders with electromagnetic vibration
}

\author{
A. L. Bespalov, I. G. Svidrak, O. O. Boiko \\ National University “Lviv Polytechnic”, Lviv, Ukraine
}

Article info

Received 11.01.2021

Received in revised form 15.02.2021

Accepted 16.02.2021

National University "Lviv Polytechnic", S. Bandera Str., 12, Lviv, 790013, Ukraine.

Tel.: +38-066-229-50-87

E-mail:svidrak99@gmail.com
Bespalov, A. L., Svidrak, I. G., \& Boiko, O. O. (2021). Increase the functionality of vibration feeders with electromagnetic vibration. Scientific Messenger of Lviv National University of Veterinary Medicine and Biotechnologies. Series: Food Technologies, 23(95), 33-37. doi: $10.32718 /$ nvlvet-f9506

Under modern conditions vibrating hopper feeders with electromagnetic drive are irreplaceable when it comes to production processes in mechanical engineering and instrument making optimization processes. They are used to download small, medium or miniature details to automated technological equipment, such as automatic machines, automatic lines and automated complexes, or any other flexible automated production. The vibrating hopper loading devices are most commonly used in transportation and loading of details on working positions of assembly automatic machines and assembly automated complexes. In this case the details must be issued in a clearly oriented state. For this purpose, the stationary automated orienting devices, or the orienting devices located directly on the working vibrating feeders 'bodies are used. Low compressed air pressure is often used in these devices. Apart from this, in some cases the low compressed air pressure is used in vibrating feeders to increase the maximum lifting angle when vibrating transportation of details on a transport tray of the feeder. We already know the designs of vibrating feeders, whose transport tray is equipped with channels and openings for the supply of compressed air, whose jets affect the parts that are transported in order to increase the maximum possible lifting angle or the speed of parts transportation, as well as to ensure the guaranteed gap between them at the download position. We also know the vibrating feeders ' constructions equipped with jet pneumatic devices, which are set exactly on the vibrating feeder hopper and serve for non-contact orientation of details that are issued. All of these devices use the low compressed air supplied by means of the flexible pipeline from a workshop pneumatic network. But the fact that such network is simply absent in many enterprises ' workshops makes it impossible to use the vibrating feeders like these, this way decreasing their use. For expanding their use it is necessary to have vibrating feeders with individual low pressure compressed air source. Modern production manufactures new models of machines with high technical economic indicators, so functionality increase of the existing one equipment and the development of new schemes of machines is an important task for designers and technological equipment manufacturers, because minimal improvement of its technological and performance can lead to a significant economic effect. The set of elements affecting the performance and efficiency of vibrating bunker feeders with electromagnetic drives that have a directional elastic system are presented in this paper. The additional structural elements increasing the functionality of such feeders are offered.

Key words: vibration transportation, productivity, vibrating feeder, work efficiency, functional ability, elastic system, variable volume cameras, coefficient of performance.

\section{Збільшення функціональних можливостей віброживильників електромагнітним вібраційним приводом}

\author{
А. Л. Беспалов, І. Г. Свідрак, О. О. Бойко \\ Національний університет “Львівська політехніка”, м. Львів, Украӥна
}

Вібраційні бункерні живильники з електромагнітним приводом в нам час незамінні при автоматизації виробничих процесів у машинобудуванні та приладобудуванні. Вони застосовуються для завантаження дрібних, середніх або мініатюрних деталей до 
автоматизованого технологічного обладнання, такого, як верстати-автомати, автоматичні лінії та автоматизовані комплекси або будь-які інші гнучкі автоматизовані виробництва. Найбільше розповсюдження вібраційні бункерні завантажувальні пристрої отримали для транспортування та завантаження деталей на робочі позииії складальних автоматів та складальних автоматизованих комплексів. В иьому випадку деталі мають бути подані у чітко зорієнтованому стані. Для иьього використовують стаціонарні автоматизовані орієнтуючі пристрої або орієнтуючі пристрої, щяо розташовані безпосередньо на робочих органах віброживильників. Дуже часто у цих пристроях використовується стиснене повітря низького тиску. Окрім цього, в деяких випадках стиснене повітря низького тиску використовується у віброживильниках для збільшення максимального кута підняття при вібротранспортуванні деталей по транспортному лотку живильника. Відомі конструкиї віброживильників, транспортуючий лоток яких оснамений каналами та отворами для підведення стисненого повітря, струмені якого діють на деталі, щчо транспортуються, з метою збільшення максимально можливого кута піднімання або збільшення швидкості транспортування деталей, а також для забезпечення гарантованого проміжку між ними на позиції завантаження. Відомі також конструкиії віброживильників, цчо обладнані струменевими пневматичними пристроями, які встановлюються безпосередньо на бункері віброживильника і служать для безконтактного орієнтування деталей. Всі иі пристрої використовують стиснене повітря низького тиску, шзо підводиться за допомогою гнучкого трубопроводу від цехової пневматичної мережі. Але відсутність пневматичної мережі в багатьох иехах підприємств призводить до неможливості використання таких віброживильників, тобто до зменшення сфери їхнього застосування. Для розширення сфери їх використання необхідно мати віброживильники з індивідуальним джерелом стисненого повітря низького тиску. Сучасне виробництво передбачає створення нових зразків машин з високими техніко-економічними показниками, тому збільшення функціональних можливостей існуючого обладнання і розробка нових схем машин є важливим завданням для проектантів та виробників технологічного обладнання, оскільки мінімальне поліпшення його технологічних та експлуатаційних показників може привести до відчутного економічного ефекту. В роботі розглянуто комплекс елементів, цчо впливають на продуктивність та ефективність роботи вібрачійних бункерних живильників з електромагнітними приводами, ияо мають направлену пружну систему. Запропоновано додаткові конструкційні елементи, щьо збільшують функціональні можливості таких живильникiв.

Ключові слова: вібраційне транспортування, продуктивність, віброживильник, ефективність роботи, функціональні можливості, пружна система, камери змінного об'єму, коефіцієнт корисної дії.

\section{Ветуп}

Вібраційні бункерні живильники з електромагнітним приводом в наш час незамінні при автоматизації виробничих процесів у машинобудуванні та приладобудуванні. Вони застосовуються для завантаження дрібних, середніх або мініатюрних деталей до автоматизованого технологічного обладнання, такого, як верстати-автомати, автоматичні лінії та автоматизовані комплекси або будь-які інші гнучкі автоматизовані виробництва. Найбільше розповсюдження вібраційні бункерні завантажувальні пристрої отримали для транспортування та завантаження деталей на робочі позиції складальних автоматів та складальних автоматизованих комплексів. У цьому випадку деталі мають бути подані в чітко зорієнтованому стані. Для цього використовують стаціонарні автоматизовані орієнтуючі пристрої або орієнтуючі пристрої, що розташовані безпосередньо на робочих органах віброживильників. Дуже часто у цих пристроях використовується стиснене повітря низького тиску. Окрім цього, в деяких випадках стиснене повітря низького тиску використовується у віброживильниках для збільшення максимального кута підняття при вібротранспортуванні деталей спрямованому догори транспортному лотку живильника.

В роботі (Chelomej, 1981) розглянуто конструкції вібраційних бункерних живильників, в транспортуючому лотку яких проведені канали і виконані отвори для підведення стисненого повітря, струмені якого діють на деталі, що транспортуються по цьому лотку, 3 метою збільшення швидкості транспортування деталей або збільшення максимально можливого кута піднімання їх по нахиленому догори лотку, а також для забезпечення гарантованого проміжку між ними на позиції завантаження або на робочій позиції лічильних автоматів. Відомі також конструкції вібраційних бункерних живильників, що обладнані пневмоструменевими пристроями, які встановлюються безпосередньо на бункері віброживильника і пристосовані для безконтактного орієнтування деталей, що видаються з лотка живильника на робочі позиції різноманітного технологічного обладнання. Всі ці пристрої використовують стиснене повітря низького тиску, що підводиться до них за допомогою гнучких трубопроводів від цехової пневматичної мережі. Але в багатьох цехах підприємств відсутні пневматичні мережі, що не дає можливості використання таких вібраційних бункерних живильників, зменшує сферу ïx застосування. Для збільшення функціональних можливостей таких вібраційних бункерних живильників і розширення сфери їх використання необхідно розробити віброживильники з індивідуальним джерелом стисненого повітря низького тиску.

Актуальність теми. В наш час виробництво передбачає модернізацію існуючих конструкцій а також створення нових зразків машин 3 високими технікоекономічними показниками, тому збільшення функціональних можливостей існуючого обладнання і розробка нових схем машин є важливим завданням для розробників та виробників технологічного обладнання, оскільки мінімальне поліпшення його технологічних або експлуатаційних показників може привести до відчутного економічного ефекту.

B роботі (Bespalov et al., 2020) розглянуто конструкцію і принцип дії сучасного вібраційного бункерного живильника, що має підвищену продуктивність. Він складається з робочого елементу (бункера) і реактивної плити, що зв'язані між собою направленою пружною системою електромагнітного віброзбуджувача, додаткової коливальної системи, що включає додаткові вантажі, закріплені на периферії реактивної плити через пласкі пружини, і системи амортизаторів. Ця конструкція вібраційного бункерного живильника 3 модернізованою динамічною схемою має підвищену продуктивність за рахунок збільшення абсолютної амплітуди коливань бункера при збереженні попередніх габаритів живильника і споживаної потужності 
віброзбуджувача. При роботі вібраційного бункерного живильника бункер і реактивна плита, що зв'язані між собою за допомогою основної пружної системи, здійснюють вимушені коливання з частотою, рівною частоті змушуючого зусилля віброзбуджувача. За рахунок наявності на реактивній плиті додаткової коливальної системи, що складається 3 додаткових пружин та вантажів, які здійснюють протифазні до неї коливання за рахунок кінематичного збудження, здійснюється перерозподіл амплітуд коливань бункера і реактивної плити щодо нерухомої основи, який приводить до суттєвого збільшення продуктивності віброживильника.

Мета $і$ завдання дослідження. Для створення універсального вібраційного бункерного живильника, в якому розміщені орієнтувальні або інші пристрої, що використовують стиснене повітря і який можна застосувати у виробництвах, де немає мережі стисненого повітря, необхідно створити нову конструкцію вібраційного бункерного живильника або модернізувати існуючу для отримання вібраційного агрегата, що включає в себе віброживильник і віброкомпресор.

\section{Матеріал і методи досліджень}

Для розробки і створення нової конструкції агрегата, що включає в себе віброживильник і віброкомпресор, необхідно малопотужний вібраційний компресор прилаштувати додатково до вібраційного бункерного живильника. Але, якщо уважно розглянути конструкцію живильника, що має підвищену продуктивність, стає очевидним, що можна об’єднати обидві конструкції в одну 3 додаванням незначної кількості нових деталей, використавши той самий вібраційний привід, і отримати вібраційний агрегат, що включає в себе віброживильник і віброкомпресор. Це дає змогу розширити сферу застосування такого вібраційного бункерного живильника.

\section{Результати та їх обговорення}

Для досягнення поставленої мети авторами запропонована нова конструкція, що являє собою вібраційний агрегат, який може подавати деталі у орієнтованому положенні до робочої зони автоматизованого технологічного обладнання завдяки закріпленим на ньому пневматичним орієнтуючим пристроям i не споживати при тому необхідного для цього стисненого повітря від зовнішнього постачальника, а виробляти його безпосередньо у вібраційному бункерному живильнику.

У варіанті, який запропоновано авторами розробки, всі основні елементи конструкції вібраційного бункерного живильника залишаються без зміни, а модернізації підлягає лише реактивна плита, до якої через пласкі пружини закріплені додаткові вантажі, що виконують функцію динамічних гасників коливань цієї плити. Для цього між реактивною плитою і додатковими вантажами закріплюються нові елементи. В кожному з пазів реактивної плити попарно розміщено камери змінного об'єму між стінками пазів і торцями додаткових вантажів. Ці камери можуть бути у вигляді еластичних сильфонів (наприклад, гумових) або у вигляді камер з гумовими мембранами, як у вібраційних компресорів невеликої потужності. В додаткових вантажах зроблено канали, що з'єднують камери змінного об'єму з атмосферою, і встановлені впускні клапани компресора, а в реактивній плиті зроблено канали, що з'єднують камери змінного об'єму з ресивером, який може бути розташований в порожнині під конусом чаші-бункера, і встановлені нагнітальні клапани компресора.

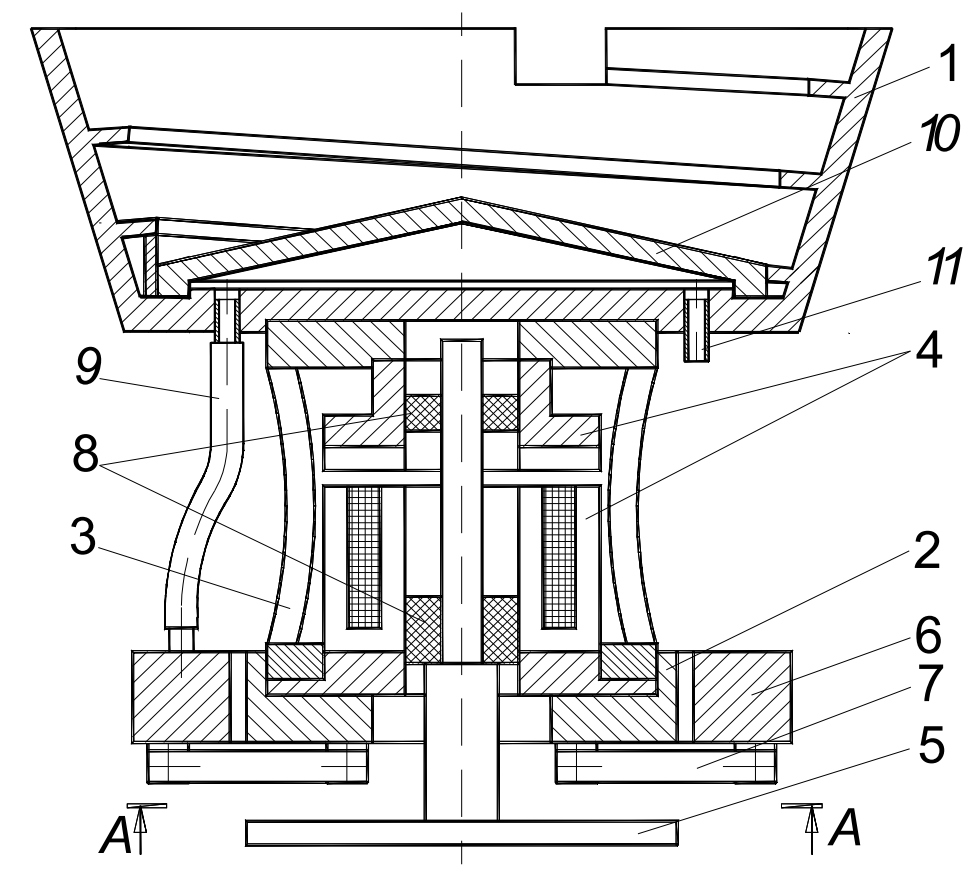

Рис. 1. Конструктивна схема вібраційного живильника 
Вібраційний бункерний живильник працює таким чином. При підключенні електроживлення до електромагнітного вібраційного приводу коливань 4 бункер 1 (рис. 1, рис. 2) і реактивна плита 2, що з'єднані між собою пружною системою у вигляді гратчастого гіперболоїдного торсіону 3 , здійснюють протифазні коливання $з$ частотою змушуючого зусилля вібраційного приводу 4.

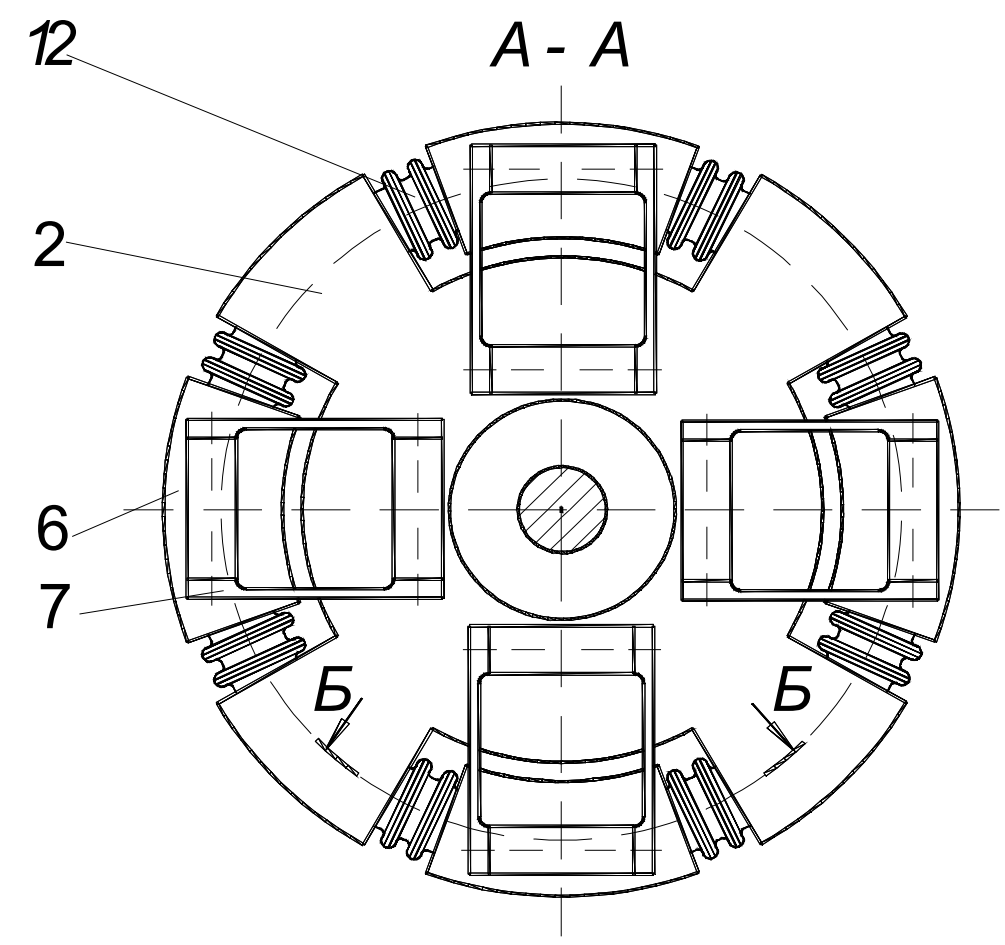

Рис. 2. Вигляд знизу, -- розріз по А-А

При коливанні реактивної плити 2 за рахунок кінетичного збудження здійснюють коливання додаткові вантажі 6, що закріплені на ній через пласкі пружини 7. Це відбувається за рахунок того, що власна частота коливань вантажів 6 на пружинах $7-47 \ldots 49$ Гц, а частота змушуючого зусилля вібраційного приводу коливань - 50 Гц. Тобто частота близька до резонансної. Вантажі 6 коливаються протифазно щодо коливань реактивної плити 2 за рахунок того, що власні частоти коливань вантажів 6 на пружинах 7 нижчі за частоту змушених коливань реактивної плити 2 жи- вильника. Додаткові вантажі 6 діють як інерційні динамічні гасники коливань. За рахунок цього вони зменшують горизонтальну складову амплітуди коливань реактивної маси 2 щодо нерухомої основи 5 (Chelomej, 1978). Завдяки цьому проміжок в пазах між торцями додаткових вантажів 6 і стінками пазів реактивної плити 2 то збільшується, то зменшується. Таким чином, камери змінного об'єму 12 то стискаються, то розтягуються з частотою, що дорівнює частоті коливань вібраційного бункерного живильника.

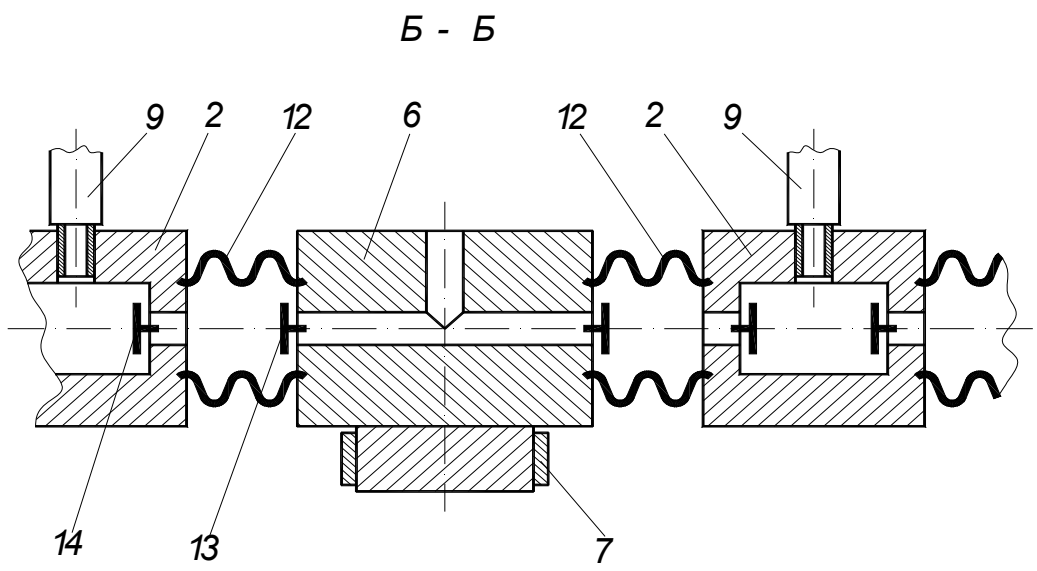

Рис. 3. Конструктивна схема віброкомпресора, -- розріз по Б - Б

При розтягуванні камери 12 закривається нагнітальний клапан 14 і повітря з атмосфери заповнює цю камеру через канали в додатковому вантажі 6 і впускний клапан 13 (рис. 3). При стисканні камери 12 впус- 
кний клапан 13 закривається і стиснене повітря через нагнітальний клапан 14 по каналах у реактивній плиті 2 нагнітається до ресивера під конусом 10 через гнучкий трубопровід 9. 3 ресивера в разі потреби можна підвести повітря через штуцер 11 гнучкими трубопроводами до відповідних пневматичних пристроїв орієнтування або інших пневматичних пристроїв, які розташовані на пристрої та необхідні для нормального вібраційного транспортування і орієнтування деталей, що переміщуються по лотках живильника. Для зменшення вібрації, що може передаватись на нерухому основу 5, віброживильник на ній закріплено через систему амортизаторів 8, які майже повністю ізолюють конструкцію від впливу вібрації на цю основу.

В зв'язку з тим, що тиск повітря при виході із сопел пневматичних орієнтуючих пристроїв майже дорівнює атмосферному, приблизну продуктивність отриманого вібраційного компресора можна визначити за такою залежністю:

$$
Q=K \cdot \pi \cdot r^{2} \cdot A \cdot n \cdot f
$$

де $K$ - коефіцієнт стискання, що залежить від величини мертвого простору компресора, $r$ - радіус камери змінного об'єму, $A$ - розмах коливань вантажів 6 щодо реактивної плити $2, n$ - кількість камер 12 , $\mathrm{f}$ - робоча частота коливань віброживильника.

При випробуванні виготовленого експериментального взірця такого вібраційного агрегата було отримано продуктивність вібраційного компресора у межах 100...200 літрів за хвилину залежно від амплітуди коливань робочого органу віброживильника при діаметрі камер змінного об'єму - 40 мм і кількості камер - 8 штук. Така продуктивність повністю забезпечувала стабільну роботу двох пневматичних орієнтуючих пристроїв, що були закріплені на бункері вібраційного бункерного живильника.

\section{Висновки}

Завдяки тому, що між додатковими вантажами 6 i стінками пазів у реактивній плиті 2 встановлені камери змінного об'єму у вигляді гумових сильфонів, а додаткові вантажі та реактивна плита здійснюють протифазні коливання одне щодо одного, то ці камери при роботі вібраційного бункерного живильника то стискаються, то розтягуються. Розмістивши впускні та нагнітальні клапани у з'єднувальних каналах реак- тивної плити і додаткових вантажів пристрою отримано вібраційний компресор, що приводиться в дію за рахунок кінетичної енергії додаткових вантажів, що коливаються. Таким чином, вібраційний бункерний живильник перетворюється на агрегат, який не тільки транспортує і видає деталі на робочі позиції технологічного обладнання, а й продукує стиснене повітря низького тиску, яке можна використовувати для приводу пневматичних орієнтувальних пристроїв або іншого технологічного обладнання, що розташоване безпосередньо у бункері або на транспортуючих лотках віброживильника. Таким чином, кінетична енергія вантажів 6, що до того часу ніяк не використовувалась, у запропонованій конструкції використовується для отримання стисненого повітря низького тиску.

Перспективи подальших досліджень. Після виготовлення дослідного взірця вібраційного бункерного живильника за поданою в роботі конструкцією необхідно експериментально визначити вплив роботи вібраційного компресора, який вносить затухання у загальну коливальну систему цілого пристрою, на характеристики роботи вібраційного бункерного живильника загалом.

\section{References}

Bespalov, A. L. (1990). A.S. 1558809. Vibracionnyj bunkernyj pitatel'. 15 (in Russian).

Bespalov, A., Svidrak, I., \& Boiko, O. (2020). Improving the performance of vibration feeders with an electromagnetic vibration drive and a combined vibration system. Scientific Messenger of LNU of Veterinary Medicine and Biotechnologies. Series: Food Technologies, 22(93), 26-30. doi: 10.32718/nvlvet-f9305.

Chelomej, V. N. (1978). Vibracii v tehnike: spravochnik v 6-ti t. M.: Mashinostroenie.T. 6: Zashhita ot vibracii i udarov; pod redakciej K. V. Frolova. M. (in Russian).

Chelomej, V. N. (1978). Vibracii v tehnike: spravochnik v 6-ti t. M.: Mashinostroenie. T. 1: Kolebanija linejnyh sistem. pod redakciej V. V. Bolotina. URL: http:/www.zodchii.ws/books/info-1219.html (in Russian).

Chelomej, V. N. (1981). Vibracii v tehnike: spravochnik v 6ti t. M.: Mashinostroenie. T. 4: Vibracionnye pro-cessy i mashiny. URL: http://www.zodchii.ws/books/info1222.html (in Russian). 